John A. Tatom is an assistant vice president at the Federal Reserve Bank of St. Louis. Jonathan Ahibrecht provided research assistance.

\title{
Is an Infrastructure Crisis Lowering the Nation's Productivity?
}

\begin{abstract}
T
LHE STATE OF THE NATION'S public capital stock and its importance to the nation's overall economic well-being have become the subject of widespread speculation, investigation and concern. This concern has been reinforced by a decline in the rate of growth of the public sector capital stock that began in the 1970s. This decline, some analysts argue, caused stagnation of U.S. productivity growth and a corresponding decline of the nation's standard of living and in its international competitiveness. "These analysts conclude that increased federal infrastructure spending is an urgent national priority with high expected returns. Their view is referred to as the infrastructure deficit hypothesis below. Candidates for the presidency in the 1992 elections lent credibility to this view and expressed strong commitment to boosting infrastructure spending. ${ }^{2}$ (The Clinton Administration's infrastructure program, called "Rebuild America" and announced in February 1993, is described in the
\end{abstract}

1See especially Aschauer (1989b,c) and Munnell (1990b). Aschaver has referred to the infrastructure problem as the nation's third deficit (presumably along with federal budget and trade deficits), hence the view supported by his work is referred to as the infrastructure deficit here. Reich (1991) provides a useful summary of the view that there is an intrastructure deficit and that attention to it should be a central national priority.

${ }^{2} \mathrm{~A}$ more traditional view of the role of public capital formation emphasizes its use a countercyclical tool for altering shaded insert on page 14.) This article reviews the claims made by proponents of the infrastructure deficit view and the evidence against it.

\section{WHAT IS INTHASTITUCTURE?}

Infrastructure refers to the relatively large physical capital facilities and organizational, knowledge and technological frameworks that are fundamental to the organization of communities and their economic development. It includes legal, educational and public health systems; water treatment and distribution systems; garbage and sewage collection, treatment and disposal; public safety systems, such as fire and police protection; communications systems, public utilities and transportation systems. The federal government's principal involvement in infrastructure formation involves the military, legislative and judicial functions. The components of infrastructure in these areas largely are not physical capital, nor is the largest physi- aggregate demand, output and employment. Recent policies adopted in Japan and proposed in the European Community (EC) take this approach. See $M$ MF (1993, p. 34) and EC (1993) for discussions of the specific Japanese proposals of August 1992 and April 1993, and the June 1993 EC summit proposals, respectively. The discussion in each case emphasizes the conventional effects on aggregate demand and employment that some analyses suggest can arise from countercyclical fiscal stimulus programs. 
cal component of public sector infrastructure, national defense, generally included in the discussion of the infrastructure deficit hypothesis. In this article, public infrastructure-or the public capital stock-is defined narrowly to include only tangible, nonmilitary public capital goods. ${ }^{3}$

The key word in describing infrastructure above is system. Infrastructure typically requires relatively large initial capital outlays to provide services potentially to all persons in a geographic area; its incremental services are relatively cheaply provided to any new household. In many cases, physical units of infrastructure capital come in relatively large and "lumpy" units, such as highways, plants and buildings.

Table 1 provides a detailed breakdown of the components of public capital at the end of 1992 , measured in current prices. This measure of the capital stock, which is net of depreciation, is an estimate of the replacement cost of capital at current prices; it is prepared by the Bureau of Economic Analysis of the U.S. Department of Commerce. The constant-dollar (1987 prices) net stock is used below to compare trends in the volume, or quantity, of public capital. The collection of public sector physical plant and equipment includes a broad range of capital goods, some of which, especially when held under private ownership, are not commonly thought of as infrastructure, and some which are not related to any special function of government.

\section{Public vs. Private Inf rastructure}

Much of the infrastructure in a highly deve. loped market economy such as the United States' is privately provided and managed. Some examples include most electric and gas utilities; communications firms, such as telephone, radio, television and cable services; private educational institutions; and private providers of transporta. tion services. Similarly, local governments have recently begun to privatize infrastructure by selling off public assets, contracting for the capital services (for example, private prisons or police), or mandating that private developers provide infrastructure capital to secure development approval. Significant private sector initiatives in areas like telecommunications, transportation and waste processing dominate U.S. infrastructure developments. Recently, mergers and joint ventures by cable companies, the Baby Bells, entertainment and other information and communication firms have accelerated the development of private communications infrastructure, especially the so-called information superhighway.

Other nations lead the way in privatizing pub. lic capital facilities, especially telecommunications and transportation, to promote efficiency and improve the quality and quantity of capital services, or simply to raise government revenue. While relatively more of these countries infrastructure has been provided by the public sector in the past, many are currently privatizing infrastructure and shifting to private sector provision. Prominent examples include the Mexican and other telephone companies, the earlier privatization of Mexico's airlines, the privatization of infrastructure activities in Eastern European countries, and recent proposals to privatize Failroads, airlines and communications systems in western Europe. ${ }^{4}$ The Japanese telephone company, Nippon Telephone and Telegraph (NTT), was privatized in 1985 and Japan recent ly began to privatize its railways.

\section{THE INFEASTRUCTURE DEFICIT VIEV AND TRENDS IN PUBLIC CAPITAL FORMATION}

According to the infrastructure deficit hypothesis, a decline in public capital formation began in the early 1970 s and has reduced productivity in the nation's business sector. In addition, the hypothesis continues, the decline has reduced the rate of return to private capital formation, so that private capital formation has been reduced as well. This, in turn, has further lowered private sector productivity. Since productivity is the principal determinant of the nation's income per capita, the decline has caused, ac-
This choice follows the practice of other researchers who refer to this measure of public capital as infrastructure. Other definittons, however, have been used. For example, a narrower definition can be found in the U.S. Congressional Budget Office (CBO, 1992), which defines infrastructure to include highways, mass transit, rail, aviation, water transportation, water supply and waste water treatment. The study indicates that some of the excluded areas could also be considered to be infrastructure.
4For example, the EC leaders agreed on June 16, 1993, to end state-owned telephone monopolles in six EC nations by 1998, while four other countries (Greece, Portugal, Spain and (reland) were given an additional five years, and Luxembourg and, perhaps, Belgium were given two additional years. See Wall Street Joumal (1993) and Reuters Limited (1993). 
Table 1

\section{The Composition of the Net Stock of Public Capital: 1992} (end of year, billions of dollars)

\begin{tabular}{|c|c|c|c|c|}
\hline & tredegal & $\begin{array}{l}\text { State and } \\
\text { local }\end{array}$ & Tola & 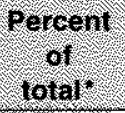 \\
\hline Nonnilltary stradures & $\$ 247.6$ & 818560 & 101086 & $(00.6 \%$ \\
\hline 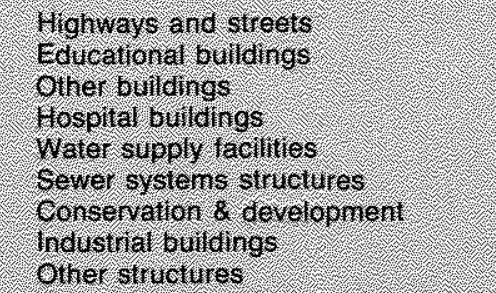 & 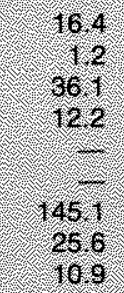 & 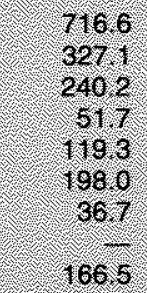 & 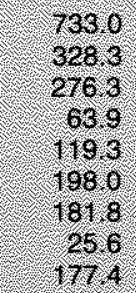 & 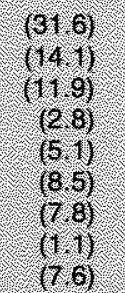 \\
\hline Wonnular. equipriert & 623 & 1867 & 2180 & $(9.4)$ \\
\hline Aonnintay structures and equiniten & 3098 & 20116 & 2,0214 & $(160)$ \\
\hline Minary equpriner) & 120.9 & & 4209 & \\
\hline Tolal (nefuding nillary) & 8460 & 20.16 & 28570 & \\
\hline
\end{tabular}

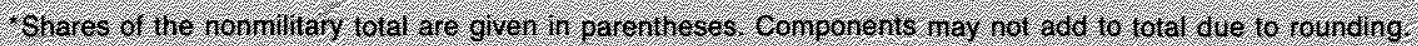

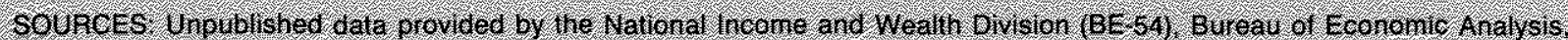
U.S Deparinent of Cominerce.

cording to this view, a decline in the nation's real income and international competitiveness. ${ }^{5}$

The growth of the nation's stock of public sector capital slowed sharply in the late 1960 s and in the early $1970 \mathrm{~s}$. The infrastructure deficit view focuses on this decline in the trend growth of public capital. ${ }^{6}$ Figure 1 shows the net stock of nonmilitary fixed public sector capital meas. ured in 1987 prices. While the capital stock has climbed steadily, its growth rate slowed in the early 1970s. Proponents of the infrastructure deficit view often measure the public capital stock relative to private sector employment and show that such capital per worker fell begin. ning in the mid-1970s. In their view, public capital yields services in private sector production so that, like private capital, its contribution is best assessed by measuring its quantity relative to private sector employment. Public capital is aimed at providing services to all residents, however, especially children and the aged. Thus, a broader assessment is afforded by its availability per person.

On a per capita basis, the public capital stock (Figure 2), including the federal as well as state and local governments, nearly doubled between
5An earlier debate over the role of infrastructure focused on many of the same issues as the recent discussion of pubu lic capital formation. This earlier literature concerned the mainstrearn view of the indispensable rote of the railroad in 19th-century economic growth. Fogel (1964) relied heavily on the role of substitutability of competing transportation modes in his seminal work rejecting this hypothesis. In his analysis of the railroad's contribution, he also addressed the role of substitutability in both private and public provi sion and in financing.

There is a built-in bias in the United States tavoring ex. cessive investment in public physical capital facilities, however, which must be kept in mind in discussions of the public capital stock. This bias occurs because the public sector is not taxed on the return or benefits from public capital formation, while the private sector is taxed on the benefits from private sector capital formation. As a result, capital formation is restricted in the taxed private sector and the cost of capital to the public sector is lowered, boosting public capital. in addition, public capital formation is often financed by the sale of tax-free bonds, which means that these projects face a taxpayer-subsidized, lower cost of capital than private capital formation. If government decisionmakers look only at their direct cost of finance rather than the social opportunity cost (the before-tax return on private capital), they will tend to invest in projects with benefits that are worth less than their cost to taxpayers. In this sense, the nation would "overinvest" in public capital. 
Figure 1

Net Stock of Nonmilitary Public Capital

Billions of dollars (1987 prices)

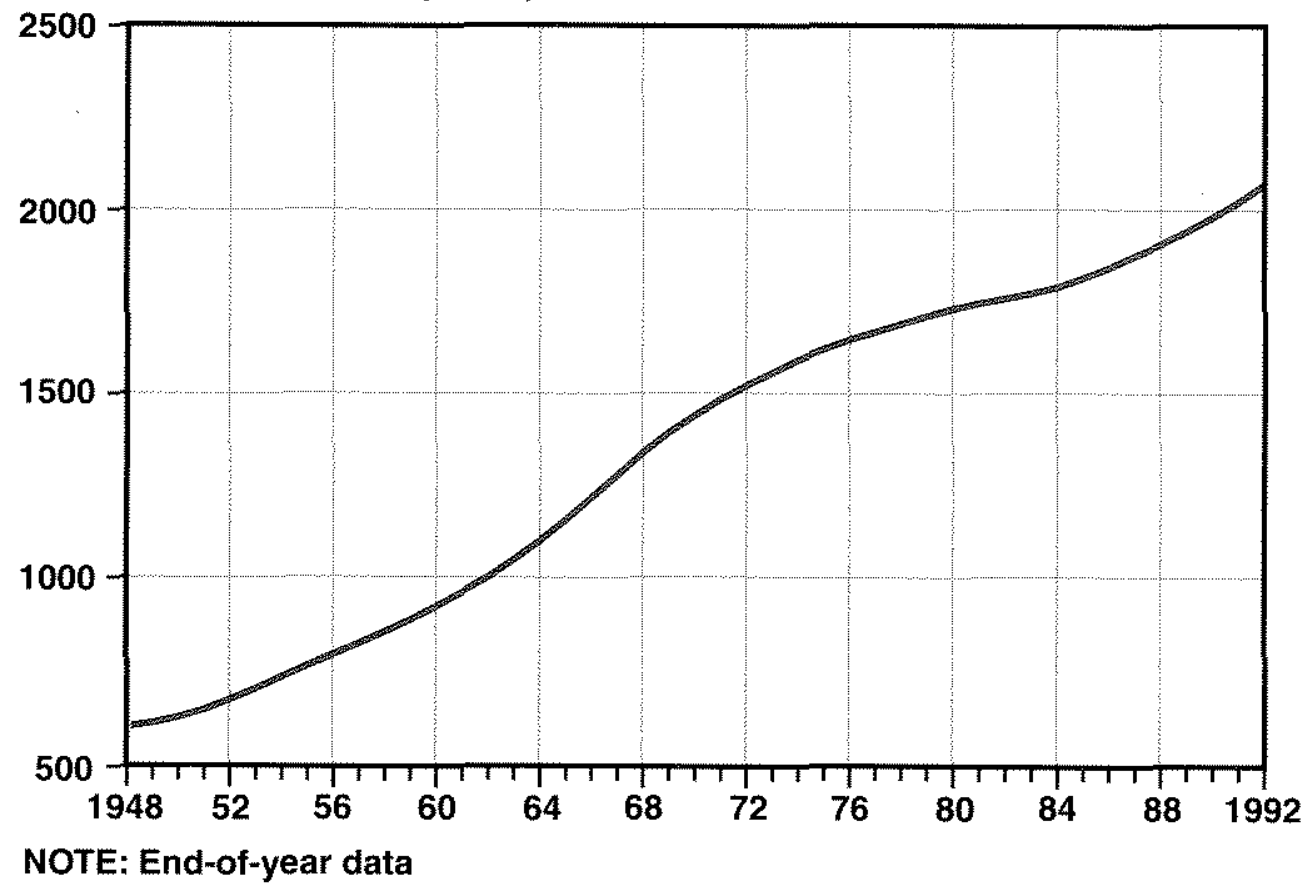

Figure 2

Real Nonmilitary Government Capital Stock per Person

Thousands of dollars (1987 prices) per person

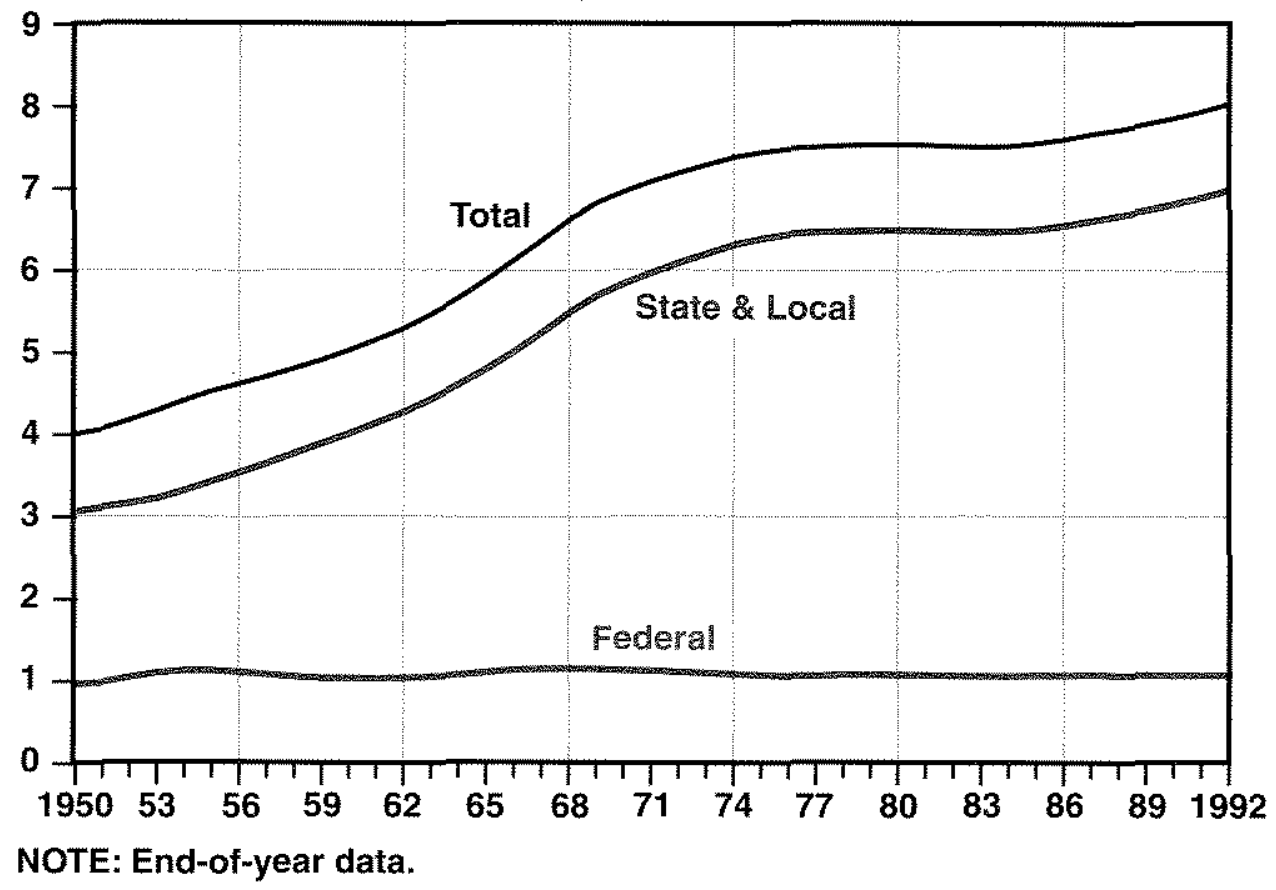


1950 and 1971 , but then showed little change for the next 20 years, averaging about $\$ 7,600$ per person, measured in 1987 prices. Such slowing is the basis for the view that the nation has been deficient in providing for its infrastructure. ${ }^{7}$ Of course, a slowing in the growth of the capital stock may reflect a decline in demand and not a deficient supply, but this is the standard used in recent discussions of the nation's public capital stock. Similarly, a rise in the public capital stock may exceed or fall short of demand growth so that, again, the change in the stock is not strong evidence about the optimality of the nation's public capital.

Advocates of the infrastructure deficit view suggest that the problem arose at the federal level and that it requires a federal solution, but these conclusions are not supported by the composition of public capital and its trends. Table 1 shows that about 86 percent of the nation's public capital stock is held by state and local governments; it is these governmental units that make decisions to augment it. ${ }^{8}$ Figure 2 also shows that federal nonmilitary capital has been about $\$ 1,100$ per person (1987 prices) since 1950. There has been essentially no upward (or downward) trend in this level, either before or after the early 1970 's.

Thus, it is difficult to see that federal government holdings of capital have played a role in the slowing in overall public capital formation. Finally, Figure 2 suggests that public capital formation resumed its growth beginning in 1984. Thus, if the previous slowing was a problem, it appears to have ended almost a decade ago.

\footnotetext{
${ }^{7}$ Seely (1993, pp. 35-7) suggests that a comparison with the earlier infrastructure trend, especially in the 1960 s and early 1970 , overstates the decline. In particular, he refers to this earlier period as the "golden age of infrastructure development in the United States." He cites the beginning of the Department of Transportation (1968), the Environmental Protection Agency (1969), and three new laws-the Solid Waste Disposal Act of 1965, the Urban Mass Transit Act of 1970 and the 1972 Water Pollution Control Act as the sources of this boom.

sSeely (1993) explains that this division of responsibility dates back to early debates over the role of the federal government in capital formation, especially for roads. Congress severely limited this role from the outset. The first major debate involved the Gallatin Plan, a proposal for federal road development, which was proposed in 1808 and ultimately rejected by Congress. In contrast, the role of the state governments dates back to early road and canal projects, especially New York Governor DeWitt Clinton's construction of the Erie Canal, "Clinton's Ditch," which set off a wave of development of state-owned or financed canals.

9See Aschauer (1989a), for example.
}

\section{An International Comparison}

Is it really true that the U.S. has fallen behind? A common criticism of U.S. infrastructure policy is that foreign countries have more infrastructure and a faster pace of infrastructure formation than the United States. ${ }^{9}$ Ford and Poret (1991) have examined the public capitalprivate productivity link for 11 major industrial countries and find that the evidence of a link is not robust. Also, criticisms of U.S. infrastructure development ignore the relatively large U.S. private sector holdings of capital that, abroad, would be held by the public sector; this is especially the case in transportation, communications, and electric and gas utilities. ${ }^{10}$ It is not possible to construct a comprehensive and exactly comparable measure of infrastructure. Analysts would differ over the types of capital, and the various sectors to be included or excluded in constructing such a measure; moreover, it is not possible to obtain comparable detail or component measures for comparable sectors.

Table 2 provides some insight into these issues. 'The size of public capital formation relative to private capital formation in eight countries, including the United States, is shown for various five-year periods since 1960 , where data are available. ${ }^{11}$ The table shows that public capital formation has generally slowed when measured relative to private capital formation or GDP in all of the countries except France. In the latest period, public capital formation continued to decline in all countries except the United States and France. Thus, the decline in U.S. public

10Ford and Poret also note the distinction between public capital and a broader measure of infrastructure by measuring infrastructure narrowly as the public captal stock of "producers of government services," and more broadly by including public and private capital stocks in electricity, gas and water, and structures in transportation and communication. They do find some support for a link between private productivity and the broader measure in a cross-country comparison, but they reject the public capital linkusing the narrower measure, and find that the significant results with the broader measure are not robust.

tThe capital formation data are from the Organization for Economic Co-operation and Development (OECD), except that this source contained no Japanese data; these were obtained from a national source. The countries shown are the only major industrial countries for which OECD reports data for most of the period. For example, data for ltaly, the only G-7 country omitted in Table 2, are reported only tor $1980-86$. 


\section{Table 2}

\section{Public Capital Formation as a Percent of Business Capital Formation}

\begin{tabular}{|c|c|c|c|c|c|c|c|c|}
\hline periog & belgivin & canada & France & cermany & Nethedands & 116 & $0 \mathrm{~s}$ & Mapan \\
\hline 196064 & 118 & $28.36 \%$ & Wris & $11,940 \%$ & N & 16287 & $18,73 \%$ & $4.66 \%$ \\
\hline 1965 69 & NA & 21.61 & $11 \mathrm{~A}$ & 1966 & $N a$ & 136 & 19.34 & 45.79 \\
\hline 197077 & NA & 1921 & 14040 & 1979 & 21.610 & 9.09 & 14.2 & 4565 \\
\hline 197579 & 20,3400 & 1529 & 14.62 & 1907 & 20.24 & 6.12 & 11.09 & 5986 \\
\hline 1586.8 & 20114 & 1404 & 1608 & 1587 & $(10,84$ & 496 & 9.8 & 56.59 \\
\hline $1967-89$ & 78.9 & 13.16 & 1636 & 18.80 & 13.50 & 4,46 & 966 & 3966 \\
\hline
\end{tabular}

\section{Share of Public Capital Formation in Gross Domestic Product}

\begin{tabular}{|c|c|c|c|c|c|c|c|c|}
\hline Feriod & Bergina & choda & France & cemaris & Altherands & U1, & Us & Japar \\
\hline 1300.64 & NA & 40786 & NA & $3050 \%$ & N1) & $1.90 \%$ & 26486 & 7,7600 \\
\hline 1966.69 & 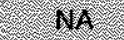 & 4. 1 ( & NA & 6.91 & Na & 129 & 279 & 707 \\
\hline $18 \% 074$ & $\pi / 4$ & 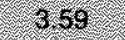 & $366 \%$ & 401 & $4.27 \%$ & 1,61 & 2,25 & 853 \\
\hline 1975,79 & $356 \%$ & 3.10 & 285 & 320 & 3. 48 & 10 & 175 & 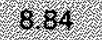 \\
\hline $1860_{64}$ & 3. & 265 & 2.75 & 280 & 295 & 018 & 1.48 & 8.45 \\
\hline $108 \mathrm{~s} .9$ & 18.4 & 243 & 278 & 231 & 2.4 & 0.76 & 1. 15 & 647 \\
\hline
\end{tabular}

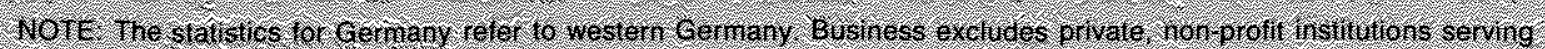

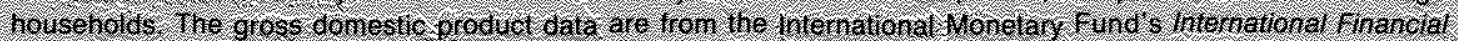
Stavitics:

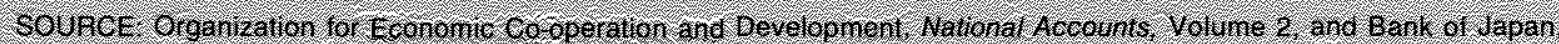

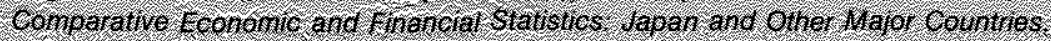

capital formation is not unique and, as a share of GDP, it is small compared with the ex perience abroad.

Table 2 also shows that relatively more of investment (and economic activity) is determined by the public sector in Europe and Japan. In most periods shown, public capital is a larger percentage of private capital formation in all of the foreign countries (except the United Kingdom) than it is in the United States. Public capital formation has generally been a smaller share of GDP in the United States, according to these data, than in any of the other countries except the United Kingdom. ${ }^{12}$ While data from the $1960 \mathrm{~s}$ are only available in a few countries, the decline in public capital formation as a share of GDP has not been smaller abroad than in the United States. Thus, it is hard to attribute any purported decline in U.S. competitiveness to a relative decline in the pace of public capital formation.

\section{WHY HAS U.S. PUBLIC CAPITAL FORMATION DECLINED?}

Two of the largest components of the nation's public capital stock (see Table 1) are highways and streets, and educational buildings. While the first is closely related to the notion of infrastructure, it is only one part of a much larger (and generally private) set of capital goods that includes automobiles, trucks, buses and trailers, which are involved in the provision of transportation services. Educational buildings (unlike the educational system, its organization, content, processes and outcomesl are less related to the infrastructure concept and also have a large private sector counterpart. These two componentshighways and streets, and educational buildings -account for most of the slowing in the growth of U.S. public capital. Figure 3 shows these two components of public capital per person and total public capital per capita excluding these two

12While France shows relatively stronger public capital formation, the French government has announced an extensive privatization program for 21 companies, including some of the largest in France. The program began in fall 1993. See Belsie (1993) and Hiding (1993). 
Figure 3

State and Local Net Capital Stock per Person

Thousands of dollars (1987 prices) per person

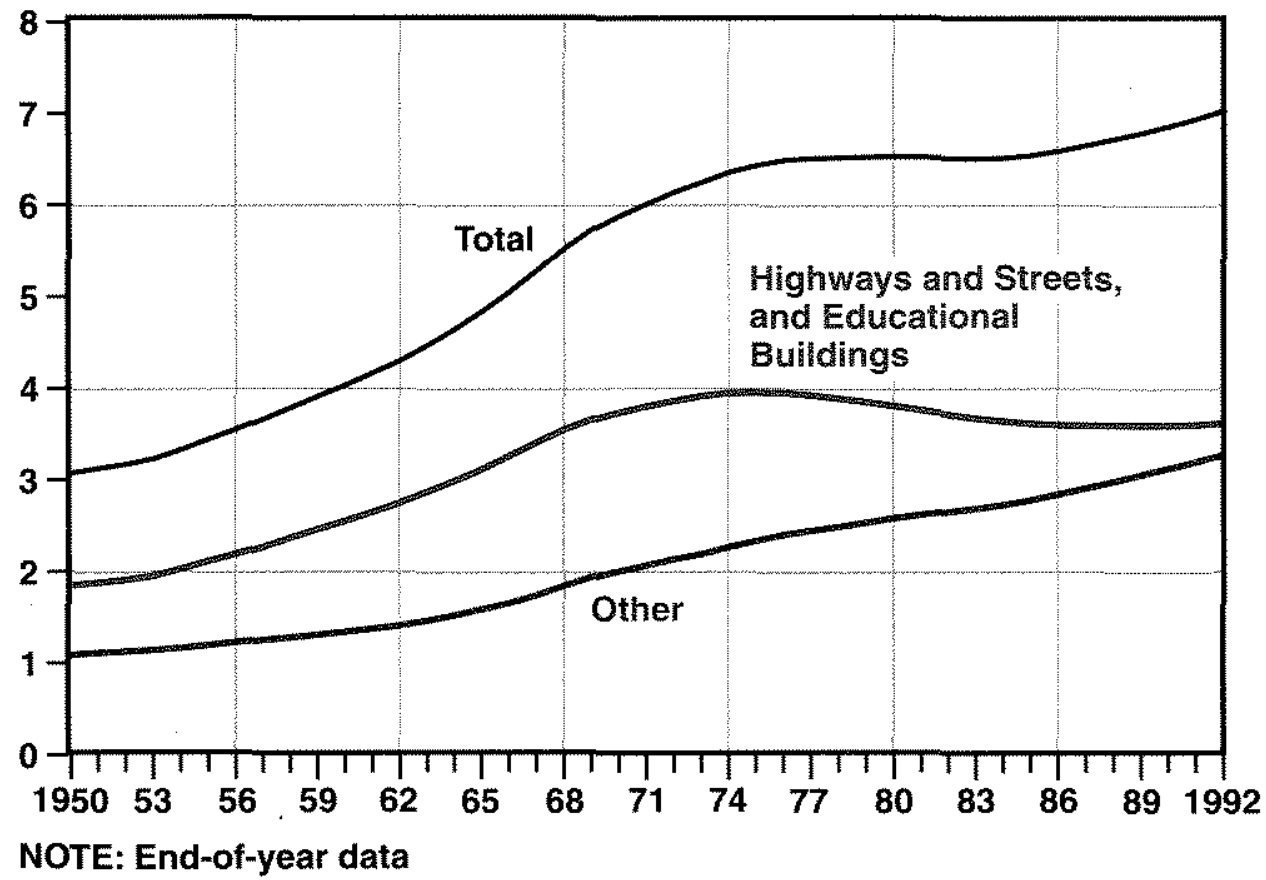

components, called "other" in the figure. Excluding these two components, there was little or no slowing in public capital formation during the 1970 s and early 1980 s.

Tatom (1991b) argues that there are three principal reasons for the slowing in highway and street, educational building, and total public capital formation. First, the post-World War II baby boom and associated temporary surge in population growth played a major role in the subsequent decline in growth of the educational buildings stock and in the earlier growth of highways and streets, especially surrounding cities. ${ }^{13}$ The interstate highway system, began in the mid-1950s and largely completed by 1975 , also contributed to a temporary surge in public capital formation and, subsequently, gave rise to part of the apparent slowing. Second, changes in the cost of driving played an important role in accounting for the decline in road capital formation. Following sharp increases in the price of oil and gasoline in 1973-74 and again in 1979-80, the growth of passenger-miles driven per person dropped very sharply. Reductions in the growth of highway and street use reduced the growth of this form of capital.

The third factor influencing roads, highways, educational buildings and other public capital formation is the price of such capital goods. From the early 1950s to the early 1960s, the

13The decline in the growth of the stock of educational buildings reflects the fact that the share of the school-age population (ages 5 to 24) rose from about 31 percent in 1949 to about 37.5 percent in 1971, then fell steadily to less than 29 percent in 1990. Not surprisingly, public educational buildings per person peaked in 1974. The subsequent dectine in public educational buildings per person was smaller than the decline in its private educational counterpart. The slowing in highway and street capital formation was similarly not unusual when compared with private capital formation associated with road transportation; see Tatom (1993). 
prices of public capital goods fell relative to the prices of private capital goods. Consistent with the law of demand, the quantity of public capital grew much faster than that of private capital goods over the period. Since then, and especially since the late 1960 s, the relative price of public capital goods has climbed sharply; not surprisingly, the demand for, and quantity of, public capital has declined relative to private capital. ${ }^{14}$

Two of the three factors depressing public capital formation began to reverse in the 1980s. The relative price of gasoline generally declined after 1980, falling dramatically in 1986, boosting road travel and the demand for highway and street capital. The share of the school-age population has nearly bottomed out as well. For example, the population ages 5 to 19 rose from 52.4 million in 1986 to 53.2 million in 1991 (the latest year available), after declining from a peak of 60.3 million in $1971 .^{15}$ Not surprisingly, school districts have responded to the recent baby "boomlet" by building new schools. From 1983 to 1992 , the stock of state and local high. ways and streets and educational buildings per person declined at a 0.2 percent rate, much slower than their 0.9 percent rate of decline from 1975 to 1983.

These two changes have resulted in a resumption of growth in the overall stock of public capital per person since 1983. During the 1975-83 period, the total stock rose at only a 1.1 percent rate, so the per capita total public stock rose at only a 0.1 percent rate. The only period of decline in the per capita total occurred from the end of 1980 to the end of 1983 , when it fell at a 0.1 percent rate. From 1983 to 1992, the growth rate of the total public capital stock accelerated to a 1.7 percent rate and that of the per capita stock rose to a 0.7 percent rate. If there was an infrastructure deficit as measured by declining public capital per person, it ended in 1983.

\section{Did Reduced Federal Funding Play a Role?}

While the closer look above at the composition of public capital and its trends shows that federal government capital formation plays a minor role in public capital acquisition and the overall trend, the federal government does play a role in financing some state and local government capital formation. This financing role could account for some of the earlier slowing in public capital formation. Tatom (1993) shows, however, that changes in federal financing do not account for the past state and local slowing. The argument there uses data on overall federal grants-in-aid to state and local governments and the latter's public capital formation relative to GDP. The total grant is the relevant gauge of federal assistance for infrastructure development because of the fungibility of funds within state and local government budgets. ${ }^{16}$ These data are plotted in Figure 4. Most of the post-1968 decline in the share of public investment in GDP occurred before the share of federal grants to state and local governments in GDP peaked in $1978 .{ }^{17}$ The share of public investment showed a further slight decline from 1978 to its 1984 level of about 2 percent of GDP, but it rose to about 2.2 percent of GDP in 1985 through 1991, despite a further decline in federal grants until 1989 .

\footnotetext{
14/n Tatom (1991b), the relative price of public capital to private capital is measured by the implicit price deflators for public nonmilitary investment and for private nonresidential fixed investment. It declined about 13 percent from 1954 to 1960 , then rose about 36 percent from 1960 to 1989 . As a result of the latter movement, in part, the quantity of constant-dollar net stock of nonmilitary public capital fell from about 58 percent of the constant-dollar net stock of nonresidential private capital in 1964 to about 42 percent in 1989.

15See Council of Economic Advisers (1993), p. 38t. The number of persons ages 20 to 24 continued to decline after 1986 , falling 1.6 million from 1986 to 1991 , so that the total for both groups may not have reached its trough in 1991 .

16Federal grants to state and local governments include funding for other programs besides capital outlays. Indeed, such grants are nearly four times as large as federal grants for state and local government spending on infrastructure
}

\author{
capital. About 60 percent of fecteral infrastructure spending \\ occurs through such grants. Also, see Moore (1992) for \\ more detailed analysis of the growth of federal spending \\ for infrastructure since 1989. \\ 1The share of federal grants for major public physical capi- \\ tal investment in GDP rose from about 0.2 percent in fiscal \\ $1948-56$ to 0.8 or 0.9 percent in 1976-80, then declined to \\ 0.5 percent in $1987-92$, according to the U.S. Office of \\ Management and Budget $(1993, p .376)$. This pattern es- \\ sentially mirrors, at a lower level, the pattern of total federal \\ grants to state and local governments.
}


Figure 4

Federal Aid to Governments and Public Investment

Percent of GDP

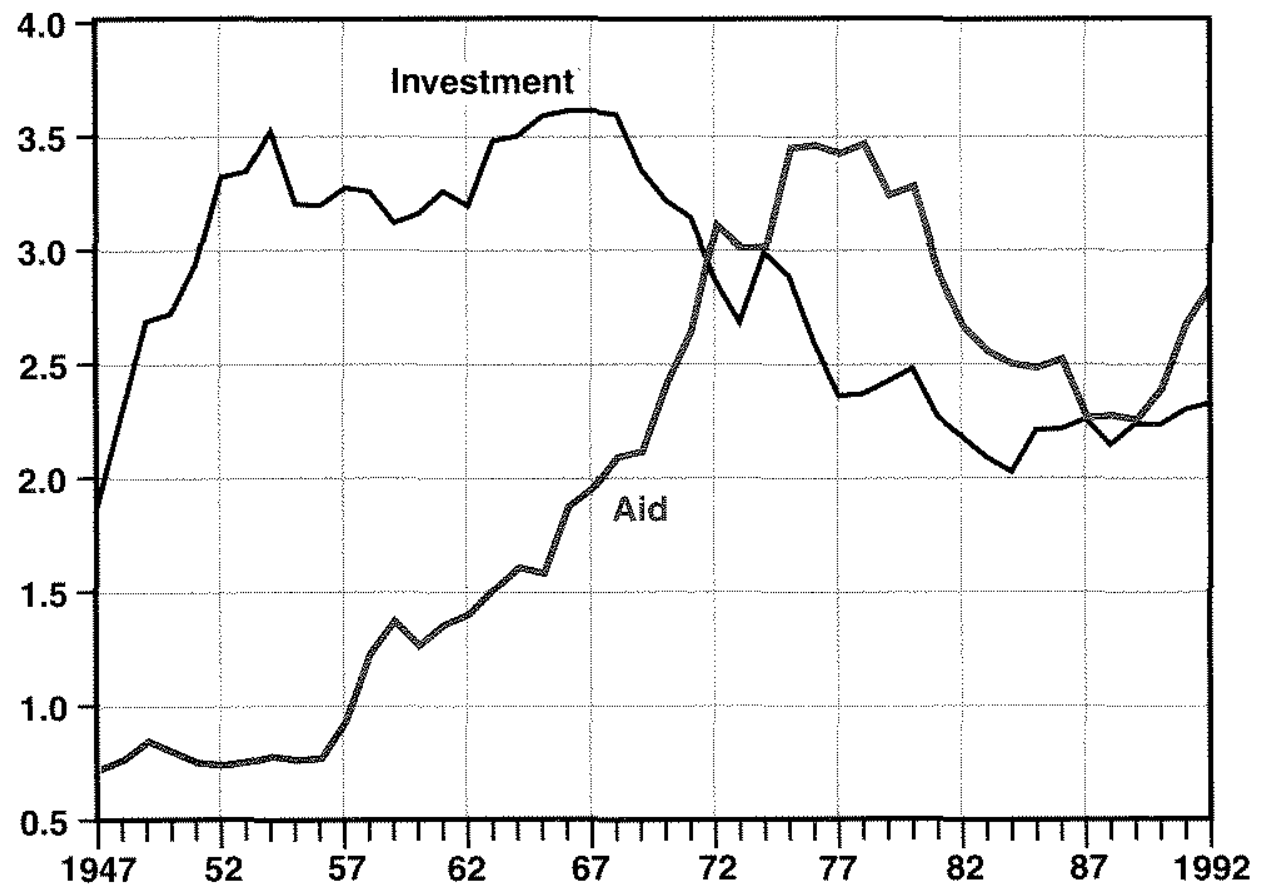

Since 1989, federal grants to state and local governments have ballooned, rising from 2.2 percent of GDP in the federal government's 1989 fiscal year to 2.8 percent in the 1992 fiscal year. These expenditures rose from $\$ 116$ billion in fiscal 1989 to $\$ 167.8$ billion in fiscal 1992 (a 44.7 percent increase); had their share in GDP not risen, such spending would have climbed to only $\$ 130.7$ billion. Despite this $\$ 37.1$ billion extra boost in funds avalable to state and local govermments, there has been no change in public sector investment as a share of GDP.

Table 3 shows federal outlays aimed directly for public capital in selected years; it also shows GDP in each year to facilitate assessments of the growth of nominal expenditures. The table shows that federal outlays aimed at state and local capital formation are much larger than direct federal outlays. The table also shows that recent growth has outstripped overall growth in the nation's GDP. From 1989 to 1993, federal outlays grew 47.4 percent, more than twice as much as the 21.6 percent rise in GDP over the same period. Over the same period, grants to state and local governments for major public capital projects rose 39.6 percent, still nearly twice the percentage increase in GDP. Despite this surge, public investment as a percent of GOP changed little after $1989 .{ }^{18}$ The overall boost in federal government funding was apparently offset by reduced funding at the state and local levels.

Such a substitution in funding is not unusual. Earlier attempts by the federal government to boost specific state and local spending components have met with such substitutions. ${ }^{19}$ Thus,

18The shaded insert to this anticle discusses the Administration's perspective on the role of public capitat formation.

such substitution effects. The CBO (1986) provides strong evidence of such substitutability. Also, see CBO (1988),

19Bartiet (1992) describes several programs to boost state and tocal government employment that failed because of sions of this phenomenon. 
Table 3

Federal Outlays for Major Public Physical Capital: Selected Years (billions of dollars)

\begin{tabular}{llll}
\hline & \\
\hline
\end{tabular}

Gop and bueget data here are for fiscal years

SOURCE Budget data for 196090 are tron 7 he Budget for fiscal Year 1991 Budget data for 1991 are trom The Eudget for Fisear Year 1993

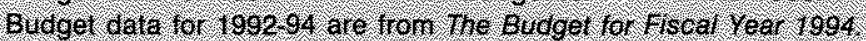

it is difficult to ensure that targeted assistance programs, such as those for public capital formation, will result in net increases in spending. New federal funding for state and local government capital spending may well finance projects that would have been done in any case; in turn, the savings these federal grants generate are used to fund more pressing current expenses instead of new capital fomation.

\section{THE QUESTIONABLE EVIDENGE FOR THE PUBLIC CAPITAL- PRIVATE PRODUCTIVITY HYPOTHESIS}

The principal damage attributed to the infrastructure deficit, according to proponents of this view, is that it led to the stagnation of pri* vate sector productivity beginning at nearly the same time as the slowing in public capital formation. Statistical estimates by Aschaver (1989c) and Munnell (1990b) indicate that the public capital stock has an unusually large effect on private sector output, given the use of fixed amounts of private sector resources. ${ }^{20}$ Criticisms of these estimates have arisen for several reasons outlined below.

\section{The Benefits of Public Capital Are Not Necessarily Reflected in Business Output}

Both Aaron (1990) and Musgrave (1990) criticize the Aschauer (1990) discussion for ignoring the fact that most of the services of public capital have no effect on measured national output, not to mention measured business sector output or, even more to the point, business sector productivity. Similarly, Aaron insists that "the argument that public sector investments contribute massively to measured national output is not strengthened by arguing that such investments contribute to items that do not appear in measured output" (p. 59). Even in the case of investments in airports or highways to reduce congestion costs, there are other benefits to the public besides increased efficiency of work and, therefore, greater business output. Time savings due to reduced congestion could result in increased work time and business output, but this

20Ratner (1983) had obtained this result earlier, although his estimate was somewhat smaller. Holtz-Eakin (1988) also obtained similar results, although later (1992 and 1993) he presented more detaited analysis for cross-section and time-series results that rejected the hypothesis. 
would not necessarily boost their ratio, or business sector productivity. ${ }^{21}$

\section{Public and Private Capital Are Substitutes}

Proponents of the link between private productivity and public capital tend to ignore substitutability in public and private capital services. ${ }^{2 z}$ Increased highway stocks, for example, could raise the rate of return to trucking firms, but these gains come, in part, at the expense of low. er social and business returns to public and private capital in water, rail and air transport. Public projects involving locks and dams, airports or roads produce services that are likely to be substitutes for each other and for private capital services as well. The presence of such a substitutability relation reduces the expected returns from public capital formation and leads to offsetting reductions in the other components of the public capital stock and in the private stock. More importantly, these substitutions offset, in part, any gain in private output directly associated with a rise in one component of public capital.

Over the period 1929 to 1991 , the growth rates (continuously compounded) of the end-ofyear public and business sector capital (measured by the constant-dollar net stock of fixed nonresidential private capital) stocks have a contemporaneous correlation coefficient of -0.287 , which is statistically significant at a 95 percent confidence level. Even within the government total there is no evidence of complementarity,

21Tatom (1993) suggests that reduced congestion and travel cost could lower real wages, leading to a lower level of marginal and average productivity of labor. The latter effect requires that the marginal and average productivity of labor are proportional and that employment rises. Output, employment and the typical consumer's standard of living all rise in this analysis, but private sector productivity does not.

22Aschaver (1989b) claims that pubiic and private capital are complements, although he finds evidence that public capital formation crowds out private capital formation, dollar for dollar. Aschauer's estimates using data on capital stocks, however, indicates that the stocks are complements. The apparent inconsistercy in these resuits is not explained. Eisner (1991) tesis the relationshp of private capital investment to public capital investment using Munnell's data $(1990 \mathrm{a}, 1990 \mathrm{~b})$ in an accelerator model. He finds evidence that public and private capital are not related, although a negative public capital formation coefficient $(-0.07)$ found in the timeweries data for 48 states suggest a substitute relationship and this effect is only marginally not statistically significant ( $t-1.75$ ) at a 5 percent level. Erenburg (1993) reports results supporting the complementarity hypothesis, although the statistical significance of the result is not indicated. The Erenberg result arises for private equipment, but not for private structures. as the growth rates for the federal stock and the state and local stock have a correlation coefficient of -0.143 ; this negative relationship is not statistically significant at the 95 percent level, however.

\section{Estimates of the Size of the Public Capital Stock Effect}

The Aschauer/Munnell estimates have been widely criticized as being implausible because of their sheer magnitude. Aaron (1990) focuses on their implausible real rate of return estimates for components of the capital stock. The real rate of return (ignoring nonmarket benefits) to private (public) capital equals what is called the marginal private sector product, or the contribution to private sector output of an additional unit of private (public) capital. Aaron points out that Aschauer's estimates imply a real rate of return to some components of public capital that is about five times that of private capital (146 percent vs. 21 to 29 percent). Such estimates imply that moving a dollar of private investment spending to such public investment would boost output by more than $\$ 1.15$ per year.

More recently, Aschauer (1993) has scaled back his estimate of the effect of public capital on private sector output. He now assumes that this marginal product of public capital is the same as that of the marginal product of private capital. ${ }^{23}$ As a result, he has also scaled back his earlier claim that the slowdown in public capital formation accounted for all of the slowing in

\footnotetext{
231f govermment decisionmakers maximize the value of the nation's resources, the opporiunity cost of public capital would be the private rate of return on private capital adjusted upward up to reflect capital income taxation. Then the marginal beneft of public capital would be equal to the marginal product of private capital services. In practice, however, the cost of capital used if public decisions lends to be lower than it is for the private sector; thus, it is more likely that the marginal product of public capital is lower than that of private capital. See the discussion of the theory and practice of cost-benefit analysis in Musgrave and Musgrave (1989). Moreover, even if it were the case that the public sector decisionmaker equates the public cost of capital to the marginal benefit of public capital, the latter is composed of marginal nonmarket benefits plus any marginal private sector product of public capital. "Thus, to the extent that government capital yields direct services to consumers, the marginal private sector product of public capital will be less than the marginal private sector product of private capital. When public decisionmakers pursue private benefits of their own, there is an additional incentive to "overinvest" in public capital by using a lower cost of public capital than otherwise.
} 


\section{The Shifting Policy Perspective on Public Capital Formation}

taron 11090 has pomted out that one of the pertivaties of the iminstructure debate

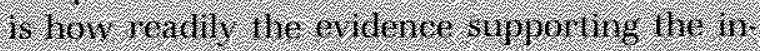
hiastrueture view was recepled despite the mplatsibilit of he estintares. he argues liat

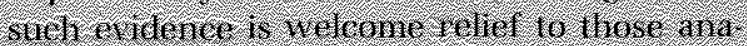
Tists who are sich and lined-nith goud rea-

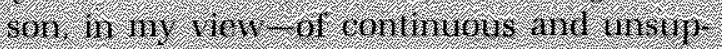
ported allogations that every thing the gonetit

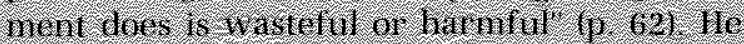
ilso ponits ant hom relcome he kind or he

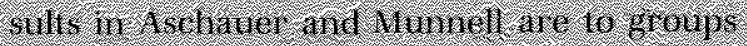
Who stand to gain from ex panded in restrue Tume spetiling

The two leading cradidates tor mestdent in II. 1992 election hroposed ins chsed ferteral Intrastrictive spendine ts eritical pionities. Tor eximple, the clinton enturign ghamed 10 hoost leder al infratruelure spending by s20 billion ench yed from 1993 to 1997 is

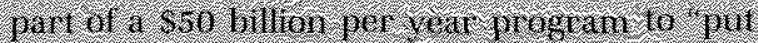

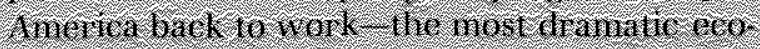
nomic gromith program since Would War II? The centerpiece of inis gron th progran, called

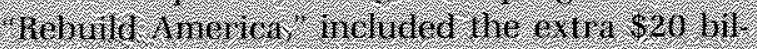
lon per ver w webuld timenica and develop the nortas lest comminiration transporta. tion and envirumental systeris t Despite the puble altertion to the problem of he na: tions phisiea infrastrieture, the prepused

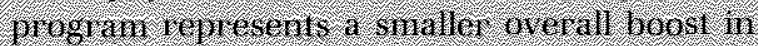
spending hian he metonic might sirggest.

More mportandy, the ytan tlso comains a naibr shill tomad teclnology developments Insteat of phy sical rapilat Ifmation hat are tratitionally the Morince of the private sector:

The table shows the Chinom Atminstra tions path of dammed new spending for he. build Anerica from 1994 to 19982 Note that lite proposed additional spending in each year

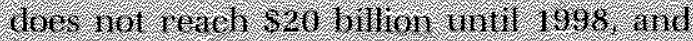
gill. then hy neluding tax meentives for ph vate capiral, Mone importantly niost of the healy s 70 billion of merrased investrient: 11 199498 are nor for puble eapind and 11 .

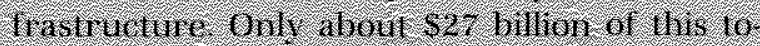

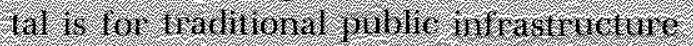
spending in trans porditun enveminentat Tural and communit development th hich also indude lumes for some lowsing stork te

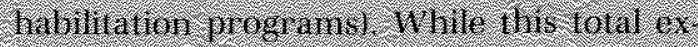
cludes nof if homing ind spending for nem techinologs development heluding shor that aireraff resentoh, lightperformance comput

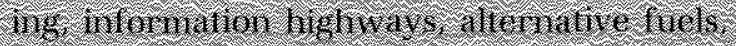
rehictes and restarchi on ratual gas. ind fir

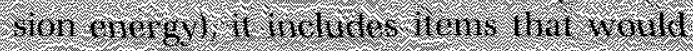
result in intle ven phy sical Capital formalion. such as sperding for snart erts smatt himt

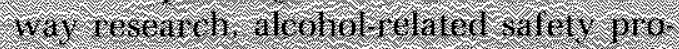
grams and commimil dexelopment hanks:

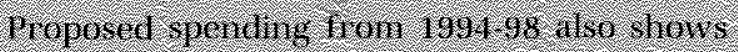
it signileant thinge in the composition of federal prograns 1 he current administration Glans to devale an ingreasing stiane of spenil. ing io minuarive activities the temphaste in infrastructure spending lins sliffed 10 infor: mation netwonts and the lechnologies of the

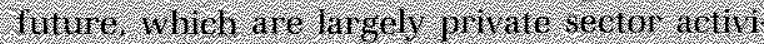
ties in the United states the technologtes for fast computing information higtivays and

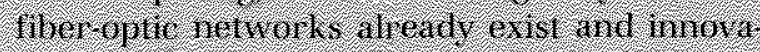
tims are being implemented in the U.S pri Vale sec ror f or example. Irrombl he use of existing super computers the internet sys: tem private phone systems, and satellie rom minite tion centers respectively) Ex parsion of ther oplie networks mid the inrodtution of Rformation highway systens by the baby. Bells tepresent continuing ef arts in extemil the use of the proetses There is ever a pri

See onntor and Gore $(1992)$

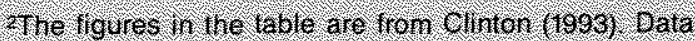

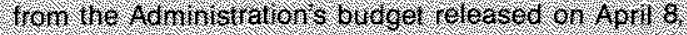
1993. difer sightiy A schader apporenlly agrees Vh

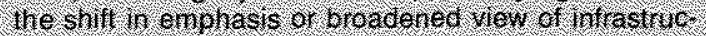
Wre described here. Acoording to we Wash haton fost (1992). Aschaver siresses 1 har not all pubric hovestrient

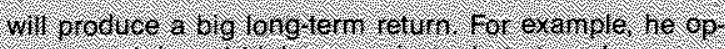

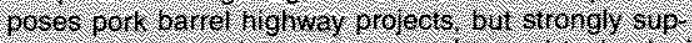
ports government hivestuent on advanced techrologies. such as - vivellgen highays. 


\section{The Clinton Budget Plan: Rebuild America Public Capital Formation (billions of dollars) ${ }^{1}$}

\begin{tabular}{|c|c|c|c|}
\hline Year & 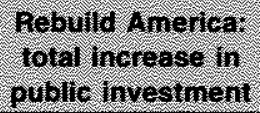 & 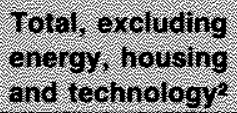 & Technology \\
\hline 1994 & $922(84.0)$ & $\$ 12$ (81 13$)$ & $6077(8) 9)$ \\
\hline 1995 & (7.2 10.19 & $41 .>(4,4)$ & 28 (6) \\
\hline 1996 & $112=1481$ & $6.0,(6,8)$ & $8.4,(5.2)$ \\
\hline 1997 & $(4,1)(18.6)$ & $74:(6.6)$ & $(1,2)(62)$ \\
\hline 1096 & 16.0 .2144 & $102,(9.9)$ & $4.5 .67)$ \\
\hline $19549 g$ & $507 / 6895$ & $269 .(31,1)$ & $15.1(23,7)$ \\
\hline
\end{tabular}

Numbors in parentheses are total investnent ounays nduding tax neenives.

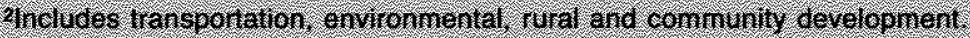

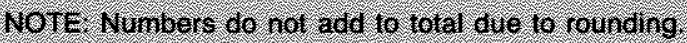

Source clinton 4 Vision of change for Amotea

vately owned and linded highspeed rai sys: tem in the planning stage in Texas:

One indicator of the shift to competition will privates sector activities is indicated in the table Revializing technology, about one: lhind of Rebuild America, includes substantial sums lor research and development in main. stream private sector activities Mast of the energy ohtlays and a substantial fraction of Transpoutation, environmental and comminity development onllays are for similar projects. Ironicaly as Butler 11992 shows, there is no evidence that total R\&D, or public ReD, in vestments slowed in the late 1970 s and 1980s, especialy to the exfent of the slowing in physi: cal public capial

The cil $(1991)$ discusses the fetleral role in spending on research and development. poining out hat retums 10 academie and Gaste research tabout onefour ih of federyl R\&I spendingl has signifieant positive effects: on private productivity bur that texcept in health and agneutire) there is no consistent evidence of significant returns from feder ally. applied run. Sinilanly (rillches 1088 ) 10 . fiects a role for Rsed movements in explaining the slowdown in private productivity growth. CBO (1991) refers to the fact hat production function estimates find no consistent, positive effects of federal contriet Rit I expenditimes: on productivity as a major puzzle:

The CBO argues that public R\&D could crawd out private fen, but that this inter: achon probably has only small overall impor: tance ${ }^{3}$ In research on new technology, how: ever, goverthment funding can orowd oul

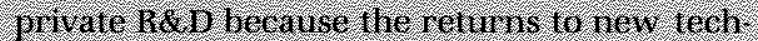
nology are not as easily caphired by private entreprenears when the lechnology is funded by the govermment. In addition govermment investment crowds ant private activity by competing for scarce speciallsed lesearch resources. The potential fro the public sector to funther tochnological innowation is open to serious doubr: While public sector R\& b in vestments may be productive, he evidenee for a larger or smaller effect of public physi. cal capital on husiness output does nor have. any bearing on the purported effects on prit vate output or productivity of public sector. spending on research and develogment.

3Buter (1992) reviews trends in hro expenditules in the

Whed states vapan and Germany.

4So calo Instivte (1993) Gilder (1998) and Rodgers.

(1998) for discussions of the privale sectorts tominance

in invertion arid inovation of hew high tectrology

intrastucture. 
private sector productivity growth after 1970 . Now, "a non-negligible portion, perhaps around 10 percent, of the productivity slump can be ex. plained by the lower rate of public capital accumulation" (1993, p. 13). The most recent estimate is based on an assumption, however, not on statistical evidence. Nevertheless, Aschauer suggests that there is "a strong causal relationship between public capital investment and productivity and output" and that "The timeseries results suggest that, at the aggregate level, there is underprovision of public capital" (1993, p. 22).

Munnell (1992) has also agreed with critics who contend that "the numbers emerging from the aggregate time-series studies are not credible." Nevertheless, she concludes that an "evenhanded reading of the evidence-including the growing body of cross-sectional resultssuggests that public infrastructure is a productive input which may have large payoffs." ${ }^{\prime 2}$ Eisner (1991) uses Munnell's (1990a,b) data to show that the time-series evidence for the 48 states in Munnell's sample rejects the infrastructure productivity hypothesis. The evidence for the variation in gross state product (not private sector output) across states shows that states with larger output have more public capital. Eisner indicates that this is consistent with an alternative hypothesis that richer states buy more public capital, as well as with the hypothesis in question-that states with more public capital produce more output. ${ }^{25}$

\section{The Spurious Regression Problem}

The time-series estimates that show a positive and statistically significant effect of the public capital stock on private sector output do so because of a statistical fallacy called "spurious regression." For example, if two wholly unrelated measures have similar time trends, then they can exhibit an apparent, statistically significant relationship between them when no economic relationship, in fact, exists. In the infrastructure case, the spurious regression problem can be observed in the relationship of private productiv. ity-business output per hour-and the stock of infrastructure per hour. Both showed relatively strong upward trends from the late 1940s to the early 1970s and then each trend declined sharply (see Figure 5).

Since the early 1980s, the evidence on the levels of private output and public capital per hour is considerably weaker. In particular, private productivity accelerated sharply, rising at a $\mathbf{1 . 7}$ percent annual rate from 1982 to 1988; meanwhile, the growth of the stock of public capital per hour actually slowed further, falling at a $\mathbf{1 . 5}$ percent annual rate from 1982 to 1988 , down from a 0.5 percent rate of increase from 1971 to $1982 .{ }^{26}$ The public capital stock per hour then began to rise, growing at a 1.7 percent rate to 1991, while private productivity growth slowed to a 0.3 percent rate. Thus, the two measures were negatively related from 1982 to 1991 . In 1992 both measures accelerated.

The spurious regression problem in Figure 5 is easily illustrated using simple correlations. The level of business output per hour and of public capital per hour are strongly and positively correlated from 1947 to 1992 ; the correlation coefficient is 0.95 , consistent with a strong, but potentially spurious, relationship. The correlation between the growth rates of

\footnotetext{
${ }^{24}$ Munnell also cites Peterson's (1990) argument that a rela* tively high voter-passage rate for infrastructure-related bond issues indicates an undersupply of public capital. Of course, voter revelations of expected net benefits from public spending could reflect either direct, nonmarket benefits, contributions to business output, or some combination of the two. Peterson found that about 80 percent of bond proposals were accepted from 1984 to 1989 by margins exceeding 66 percent on average. He argues that a "median voter" model would suggest approval rates and margins closer to 50 percent if the voters consider the stock of public capital to be about the amount desired. Tatom (1993) cites a recent approval rate higher than 50 percent $(62$ percent) as evidence for the reverse, that the public does not accept unanimously or indiscriminately capital projects offered by government officials. Recent polling results on infrastructure demand are also reported that suggest that such spending is a low priority compared with private capital formation or reducing the federal deficit, among other priorities. Therefore, it appears that voters get about what they want, just as Tiebout (1956) argued.
}

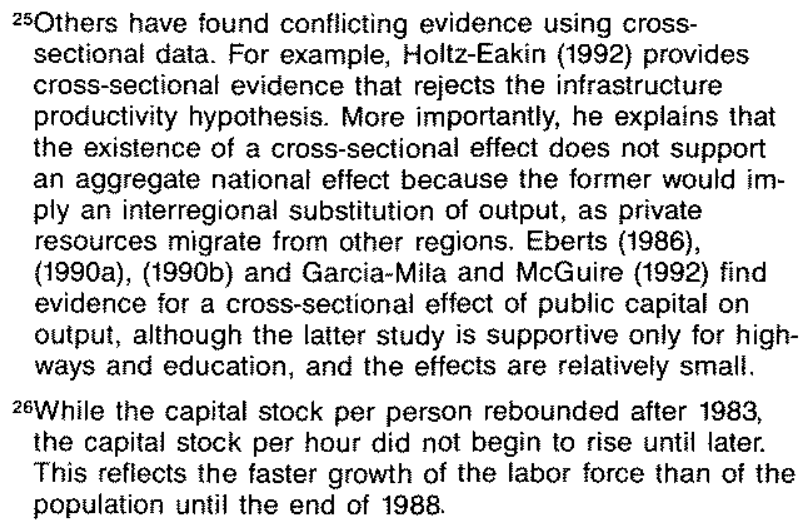
cross-sectional evidence that rejects the infrastructure productivity hypothesis. More importantly, he explains that the existence of a cross-sectional effect does not support an aggregate national effect because the former would imply an interregional substitution of output, as private resources migrate from ther regions, Eberts (1986), (1990a), (1990b) and Garcia-Mila and McGuire (1992) find evidence for a cross-sectional effect of public capital on output, although the latter study is supportive only for highways and education, and the effects are relatively small.

26While the capital stock per person rebounded after 1983, the capital stock per hour did not begin to rise until later. This reflects the faster growth of the labor force than of the population until the end of 1988 . 


\section{Figure 5}

\section{Business Sector Output per Hour and Public Capital Stock per Hour*}

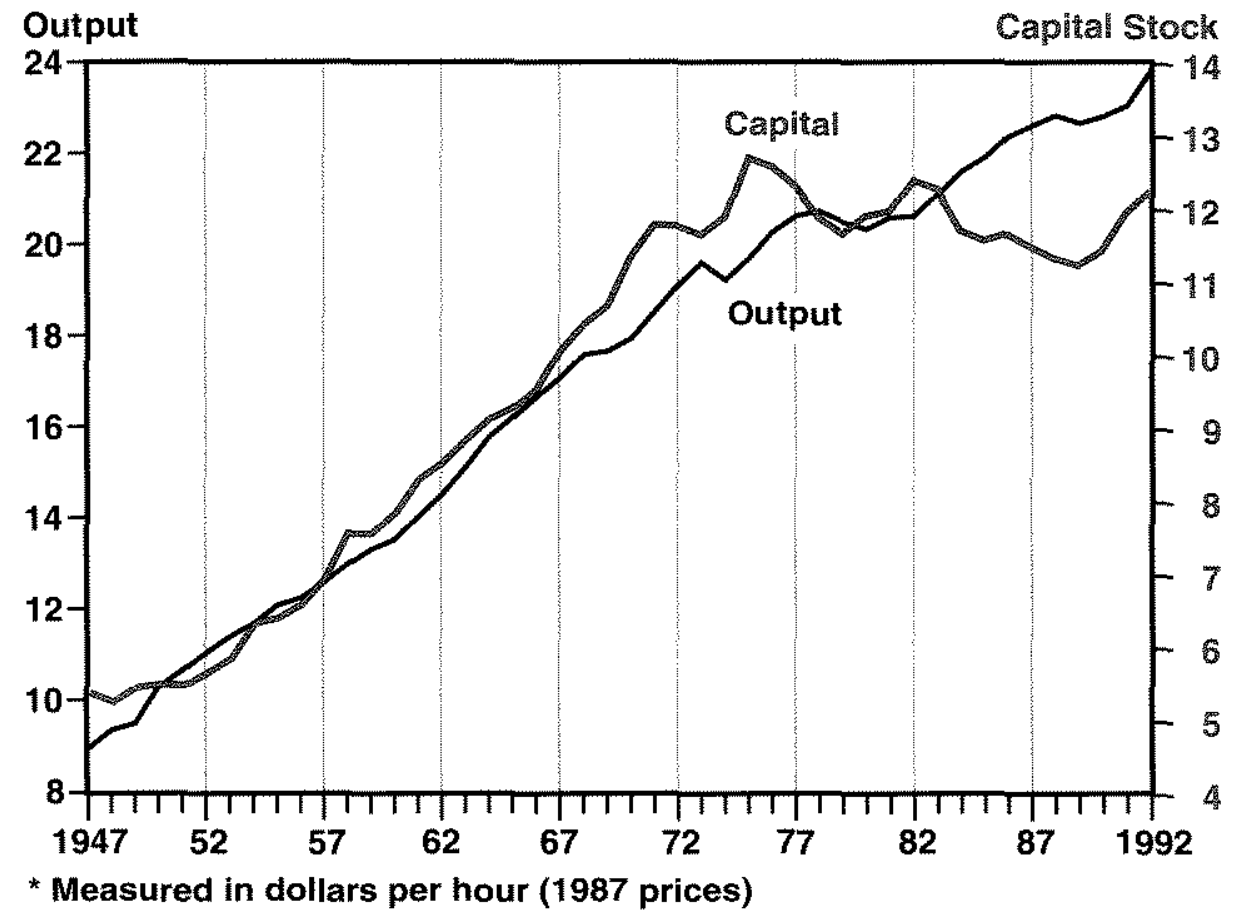

the two series, however, is not statistically significant. The correlation coefficient for the growth rates (1948 to 1992) of 0.15 is well below the critical value of 0.29 at a 95 percent confidence level. "Thus, simple correlation analysis rejects the hypothesis that a contemporaneous rise or fall in the amount of public capital per hour raises or lowers business sector productivity.

Studies of the link between public capital and private sector output do not use such a limited two-variable comparison. Instead, they attempt. to control for other factors that determine aggregate private sector production, such as private sector hours $(h)$ and the flow of private capital services $(k)$. The basic statistical model used by Aschauer, Munnell and others is a production function estimate of the form:
(1) $\ln Q_{q} / k_{t}=\ln A+\alpha \ln (h / k)$

$$
+\delta \ln \left(K G_{i} / K\right)+r t+\varepsilon
$$

where $Q_{\mathrm{s}}$ is business sector output in period $t$, and $K G$ and $K$ are the public and private capital stocks, respectively, and $\varepsilon$ is a normally and independently distributed random disturbance term. The scale parameter $A$, the rate of disembodied technological change, $r$, and the output elasticities, $\alpha$ and $\delta$, are estimated using ordinary least squares regression. ${ }^{27}$ The critical parameter for the public capital-private productivity hypothesis is $\delta$, which is hypothesized to be positive.

Estimation of such an equation requires that all of the variables entering equation (1) must have certain statistical properties for the esti-

\footnotetext{
${ }^{27}$ The specific derivation of (t) can be found, for example, in Tatom (1991a), in which the effect of energy price shocks, operating through energy use, capital obsolescence and pure technology alterations is also included, as is a quad. ratic time-trend specification,
} 
mate to be a meaningful long-run relationship. In particular, the estimation of the parameters in equation (1) requires that the error term have a distribution with a mean of zero and constant variance. Thus, the linear combination of variables that equals $\varepsilon$ also must have such a distribution. This requirement is satisfied if each of the variables entering equation (1) is stationary, which means each must have a tendency to revert to its own fixed mean. In this case, each measure is said to be integrated of degree zero, I(0). Alternatively, each series can be integrated of a common degree, typically one 1(1), meaning that each must be stationary when differenced once os", in general, differenced the number times indicated by the degree of integration. ${ }^{28}$ In the latter case, a linear combination of the variables entering equation (1) can be stationary if the variables are cointegrated.

The spurious regression problem in estimates of equation (1) arises from the fact that for the post-World War II periods used in studies of the public capital stock effect, the public capital stock variable and the term involving it in equation (1) are integrated of order two, or I(2), which means that either measure must be differenced twice to be stationary. The dependent variable in the production function is integrated of order one and $\ln (h / k)$ is also $\mathrm{I}(2)$ for the period studied in Tatom (1991a). Taken together, these properties imply that a linear combination of the levels of the variables, like the linear combination equal to $\varepsilon$ in equation (1), cannot be stationary, as required by statisti- cal theory. An estimate of such an equation can result in the appearance of statistically significant relationships when, in fact, the variables are not related. ${ }^{29}$

There are well-known statistical methods for assessing whether the spurious regression problem is present and for removing its in. fluence on statistical results. In this case, simply first-differencing the data and including a time trend in the estimate eliminates the problem because the growth rates of the two I(2) variables are trend-stationary. First-differencing the data means that the effect is estimated using data on changes (growth rates) in private sector produc. tivity and the public capital stock, along with growth rates of other factors influencing the level of private sector productivity. Firstdifferencing earlier production function estimates that include the public capital stock yields estimates of the public capital effect that are not statistically significantly different from zero. ${ }^{30}$ Both Munnell (1992) and Aschauer (1993) assert that first-differencing is inappropriate; for example, Munnell states that this operation "destroys any long-term relation in the data" (p. 193). But first-differencing equation (1) simply results in the continuous growth rates of each measure replacing the level measure of each variable; the required quadratic and linear-trend terms are replaced with a linear-trend term only and a first-order, moving-average error term is introduced. In differencing equation (1), the parameters are unaffected. Hence, if they are viewed as the appropriate long-run parameters

\footnotetext{
28ff all the variables in an equation are integrated of the same degree, they are potentaly cointegrated, regardless of the degree. Lynde and Richmond (1993) use the meas. ure in $\mathrm{KG}$ in level estimates like equation (1) to test the public capital stock effect for two periods, $1948-89$ and 1958-89. In both periods in $K G$ is $1(2)$ according to tests by the author, although Lynde and Richmond do not note this problem. Moreover, the method they use to address potentially spurious regressions, employing what are called Phillips-Hansen estimators, does not remove the possibility of spurious outcomes when the included variables are integrated of mixed order with one or more variables that are (2), or are integrated of even a higher order.

29A cointegration lest which avoids this issue is used in Tatom (1991a). In this test, the public capital stock has a negative but statisticaly insignificant effect on business sector output and productivity.

sosome of the studies that have noted this fragility include Aaron (1991), Holtz-Eakin (1988, 1992, 1993), Hulten and Schwab (1991), Jorgenson (1991), Rubin (1991) and Tatom (1991a). Finn (1993) uses the same method as Lynde and Richmond and tests various components of the public capttal stock. Her evidence supports the view that only the highway component of the public capital stock is statisticalIy significant. Her preferred measures using highway and streat capital in place of pubic capital suffer from the
}

same lack of stationarity for the growth rates of highway capital of of the ratio of public highway to private capital. Thus, her results are also spurious. This is not surprising since the time-series plots of public capitat-in total, per capita, or per unit of private capital-mirro those of highway capital. The cointegration test like that reported in tatom (199ta) for the firstudifference version of an equation like equation (1) rejects the statistical significance of the highway stock. 
in a levels estimate, they will remain so in first differences. Munnell (1992) recognizes the problems posed by nonstationarity and recom. mends testing for cointegration; Tatom (1991a) provides such a test and rejects the hypothesis. ${ }^{31}$

\section{An Alternative View: Reverse Causality}

There is an alternative view that suggests a positive link between private productivity and the stock of public capital per worker. Eisner (1991) suggests the fact that regions with relatively high productivity have relatively higher infrastructure, and simply may reflect an effect of income on the demand for and quantity of public capital.

A statistical test of whether higher productivity causes more public sector capital formation, or the reverse is true, employs "Granger causality." In these tests, causality means a statistically significant temporal relation in which changes in one measure temporally are followed by statistically significant movements in the other measure. It is possible, in principle, for each measure to "cause" the other, for neither to cause the others, or for only one measure to cause the other.

Tatom (1993) provides a test of Granger causality for the productivity public capital for. mation link. ${ }^{32}$ The test uses annual data (1949 to 1991) for the public capital stock or public sector investment and for the private sector's total factor productivity, the latter being output per

31Both Munnell and Aschauer also criticize the Tatom (1991a) results for inciuding an energy-price effect. Aschauer (1993) emphasizes that including an energy effect in a production function for a valuemadded output measure is inappropriate because energy is an intermediate input. But the insignificance of the public capital stock holds independently of whether the energy-price effect (or a quadratic trend) is included. Furthermore, a public capital stock effect also arises through intermediate input services to private firms. McMillan and Smyth (1993) include an energy-price measure in a vector autoregression model. They aiso reject the public capital-private productivity link posited by Aschauer and Munnell. The relative price of energy is usually included because it alters the quantity of energy, and it also affects total factor productivity and capital obsolescence.

Lynde and Richmond (1993) estimate the cost "dual" of the production function, a method preferred (but not used) by Munnell (1992). This method imposes long-run equilibrium efficiency conditions, however, which should not be expected to hold in the short run or in quarterly data. Berndt and Hansson (1991) and Nadifl and Mamuneas (1991) have also used the cost function approach to test the public capital hypothesis in Sweder and the United States, respectively. Both studies find that the public capital stock has relatively small effects on a measure of private cost. unit of a weighted-average bundle of both private capital and labor resources. The results indicate that neither the growth rate of the public capital stock nor the level of public sector investment cause total factor productivity growth. On the contrary, the growth of private sector productivity causes both measures of public capital formation.

One of the advantages of this approach is that it explicitly looks for statistically significant relationships between public capital formation and subsequent private sector productivity growth, and the reverse, between productivity growth and subsequent changes in public capital formation. The use of longer periods for observing expected effects allows for lags in the effect of one measure on the other. Nonetheless, this approach finds only the reverse relationship to be statistically significant.

\section{CONCLUSIONS}

The role of public capital formation and of the federal government in its provision have been the subject of widespread discussion and concern in recent years. This concern has been prompted by the infrastructure deficit hypothesis, which argues that there has been a sharp decline in public capital formation and that this decline lowered U.S. private sector productivity growth.

This article questions the infrastructure hypothesis. Trends in U.S. public capital formation indicate that the federal government's role

32Duffy-Deno and Eberts (1991) examine causality in a simultaneous equations framework for 28 metropolitan areas during the first half of the 1980 s using personal income instead of business output. Their results find causality from public capital to personal income. 
in public capital formation has been quite limited; only a small fraction of the nation's public, nonmilitary capital stock is held by the federal government and the per capita federal capital stock has been roughly constant throughout the post-World War II period

There was a slowing in the growth of state and local government highways, roads and educational buildings relative to population growth in the 1970 s and early 1980s. The demographic and energy-price changes that gave rise to reductions in the growth of demand for these goods, however, began to reverse in the early 1980s. Thus, if there was a deficit indicated by the trend in public capital formation, it seems to have begun to disappear almost a decade ago.

The purported link between public capital and private sector productivity has been widely criticized for distorting the role of public capital, yielding implausible estimates of the private sector productivity gains that could arise from public capital formation, and reversing the connection between the two. The fundamental problem with earlier estimates is that they result from spurious or unrelated movements in the quantity of public capital and business sector output and productivity. While both private sector productivity and the public capital stock per hour have risen over time, their movements have not been closely related. Indeed, in the 1980s the two measures generally moved inversely with one another. Of special note is the rebound in private sector productivity growth until 1988, which was accompanied by an accelerated decline in the stock of public capital per hour. The bottom line here is that no one has produced evidence that an increase in the nation's public capital stock will boost private sector output or productivity, within the year or even some future period. Quite simply, when the hypothesis has been explicitly tested this way, the evidence strongly rejects it.

\section{PFHERECES}

Aaron, Henry J. "Comments on 'Historical Perspectives on Infrasiructure Investment: How Did We Get Where We Are? by George E. Peterson" presented at the American Enterprise Institute for Public Policy Research Conference on "Infrastructure Needs and Policy Options for the 1990s," Washington, D.C. (February 4, 1991).

"Discussion," in Alicia H. Munnell, ed., Is There a Shortall in Public Capital Investment? Federal Reserve Bank of Boston, Conference Series No. 34 (1990), pp. 51 m 63
Aschatuer, David Alan. "Public Capital and Economic Growth", in The Jerome Levy Economics Institute of Bard College, Public infrastructure Investment: A Bridge to Productivity Growth?, Public Policy Brief No. 4, 1993, pp. 9-30 "Why Is Infrastructure Importan?" in Alicia $\mathrm{H}$. Munnel, ed., Is There a Shortfall in Public Capital Invest. ment? Federal Reserve Bank of Boston, Conterence Series No. 34 (1990), pp. 21-50.

"Public Investment and Productivity Growth in the Group of Seven," Federal Reserve Bank of Chicago, Economic Perspectives (September/October 1989a), pp. 17-25. "Does Public Capital Crowd Out Private Capital?" Journal of Monetary Economics (September 1989b), pp. $171-88$.

"Is Public Expenditure Productive?" Joumal of Monetary Economics (March 1989c), pp. 177-200.

Bartlett, Bruce. "If It Ain't Broke, Don't Fix It," Wall Street Loumal, December 2, 1992.

Belsie, Laurent. "France Relaunches Its Mid-80s Privatization Push," The Christian Science Monitor, August 3, 1993.

Berndt, Emst R., and Bengt Hansson, "Measuring the Contribution of Public Infrastructure Capital in Sweden," National Bureau of Economic Research, Working Paper No. 3842 (September 1991).

Butler, Alison. "Is the United States Losing Its Dominance in High-Technology Industries?" this Review (November/December 1992), pp. 19-34.

Cato Institute. "Is Technology Policy on the Right Track?" Cato Policy Report (May/June 1993), pp. 6-9.

Clinton, Bill, and Al Gore. Putting People First: How We Can All Change America. New York: Times Books, 1992.

Clinton, William J. A Vision of Change for America (Washington, D.C.: U.S. Government Printing Office, 1993).

Council of Economic Advisers, Economic Report of the President, 1993 (Washington, D.C.: U.S. Government Printing Office, 1993)

Duffy-Deno, Kevin T., and Randall W. Eberis. "Public Infrastructure and Regional Economic Development: A Simultaneous Equations Approach," Journal of Urben Economics (1991), pp. 329-43.

Eberts, Randall W. "Cross-Sectional Analysis of Public Infrastructure and Regional Productivity Growth." Federal Reserve Bank of Cleveland, Working Paper No. 9004, May $1990 \mathrm{~b}$.

"Public Intrastructure and Regional Economic De. velopment," Federal Reserve Bank of Cleveland, Economic Review (Quarter 1, 1990a), pp. 15-27.

"Estimating the Contribution of Urban Public Infrastructure to Regional Growth," Federal Reserve Bank of Cleveland, Working Paper No. 8610, December 1986.

Eisner, Robert. "Infrastructure and Regional Economic Performance: Comment," Federal Reserve Bank of Boston, New England Economic Review (September/October 1991), pp $47-58$.

Erenburg, Sharon J. "The Refationship Between Public and Private Investment," The Jerome Levy Economics Institute Working Paper No. 85, February 1993.

European Community. "Conclusions of the Presidency," Bulletin of The European Community (Issue 6, 1993), pp. 8-23.

Finn, Mary. "is All Government Capital Productive?" Federal Reserve Bank of Richmond, Economic Quarterly (fall 1993), pp. $53-80$.

Fogel, Robert W. Railroads and American Economic Growth: Essays in Econometric History. Baltimore: The Johns Hopkins University Press, 1964. 
Ford, Robert, and Pierre Poret, "Infrastructure and PrivateSector Productivity:" OECD Economic Studies, No. 17 (autumn 1991), pp. 63-89.

Garcia-Mila, Teresa, and Therese McGuire. "The Contribution of Publicly Provided inputs to States' Economies," Regional Science and Urban Economics (June 1992), op. 229-41.

Gilder, George. "America's Best Infrastructure Program," Wall Sireet Joumal, March 2, 1993.

Gramlich, Edward M. "State and Local Budgets The Day After It Rained: Why is the Surplus So High?" Brookings Papers on Economic Activity (1:1978), pp. 191-216.

Griliches, Zvi. "Productivity Puzzles and R\&D: Another Nonexplanation," Joumal of Economic Perspectives (fall 1988), pp. 9-21.

Holtz-Eakin, Douglas. "New Federal Spending for Infrastructure: Should We Let This Genie Out of the Bottle?" in The Jerome Levy Economics Institute at Bard College, Public Infrastructure Investment: A Bridge to Productivity Growth? Public Policy Brief No. 4, 1993, pp. 31-46.

"Public Sector Capital and the Productivity Puzzle," National Bureau of Economic Research, Working Paper No. 4122,1992

"Private Output, Government Capital, and the Intrastructure 'Crisis", Columbia University, Discussion Paper No. 394, May 1988.

Huten, Charles R., and Robert M. Schwab. "Is There Too Little Public Capital? Infrastructure and Economic Growth," paper presented at the American Enterprise institute Conference on infrastructure Needs and Policy Options for the 1990s, Washington, D.C. (February 4, 1991).

International Monetary Fund. World Economic Outlook, May 1993.

Jondrow, James, and Robert A. Levy. "The Displacement of Local Spending for Pollution Control By Federal Construction Grants," American Economic Review (May 1984). pp. $174-8$.

Jorgenson, Dale W. "Fragile Statistical Foundations: The Macroeconomics of Public Infrastructure Investment," comment on Hulten and Schwab (1991), presented at the American Enterprise Institute Conference on Infrastructure Needs and Policy Options for the 1990s, Washington, D.C. (February 4, 1991).

Lynde, Catherine, and J. Richmond. "Pubiic Capital and Total Factor Productivity." International Economic Review (May 1993), pp. $401-14$.

McMillan, W. Douglas, and David J. Smyth. "Multivariate Time Series Analysis of the Aggregate Production Func tion:" Louisiana State University Working Paper, October 1993.

Moore, Stephen. "Crisis? What Crisis? George Bush's Never Ending Domestic Budget Build-Up," Cato Institute Policy Analysis No. 173, June 19, 1992.

Munnell, Alicia H. "Policy Watch: Infrastructure Investment and Economic Growth," Joumal of Economic Perspectives (fall 1992), pp. 189-98.

"How Does Public Infrastructure Affect Regional Economic Performance?" in Is There A Shortall in Public Capital Investment? Federal Reserve Bank of Boston. Conference Series No. 34 (1990a), pp. 69-103.

"Why Has Productivity Growth Declined? Productivity and Public Investment," Federal Reserve Bank of Boston, New England Economic Review (January/February 1990b), pp. 3-22.
Musgrave, Richard A. "Discussion," in Alicia H. Munnell, ed., Is There a Shortfall in Public Capital Investment? Federal Reserve Bank of Boston, Conference Series No. 34 (1990), pp. 64-8.

and Peggy B. Musgrave. Public Finance in Theory and Practice, 5th edition (New York: McGrawHill Book Company, 1989).

Nadiri, M. Ishaq, and Theofanis P. Mamuneas, "The Effects of Public Infrastructure and R\&D Capital on the Cost Structure and Performance of U.S. Manufacturing Industries;" National Bureau of Economic Research, Working Paper No. 3887 , October 1991.

Organization for Economic Co-operation and Development. National Accounts, Detailed Tables, Volume II.

Peterson, George E. "Is Public Infrastructure Undersupplied?" in Alicia Munnelt, ed, is There a Shortfall in Public Capital Investment? Federal Reserve Bank of Boston, Conterence Series No. 34 (1990), pp. 113-30.

Ratner, Jonathan B. ${ }^{\text {}}$ Government Capital and The Production Function for U.S. Private Output," Economic Letters (1983), pp. $213-17$.

Reich, Robert B. "The REAL Economy" The Atlantic Monthly (February 1991), pp. 35-52.

Reuters Limited. "Colncl Agrees Two-Speed Phone Liberalization Plan," The Reuter European Community Report (June 16, 1993).

Riding, Alan. "France is Selling 21 Big Companies;" New York Times, May 27, 1993.

Fodgers, T. J. "What Silicon Valley Needs From Clinton," The Wall Street Journal, Apris 12, 1993

Rubin, Laura. "Productivity and the Public Capital Stock: Another Look," Board of Govemors of the Federal Reserve System, Division of Research and Statistics, Working Paper Series No. 118, May 1991.

Seely, Bruce. "A Repubiic Bound Together," Wilson Quarterly (winter 1993), pp. 19-39.

Tatom, John A. "Paved With Good Intentions: The Mythical National Infrastructure Crisis," Cato Institute Policy Analysis No. 196 (August 12, 1993).

"Public Capital and Private Sector Pertormance," this Review (May/utune 1991a), pp. 3-15.

"Should Government Spending on Capital Goods Be Raised?" this Feview (March/April 1991b), pp. 3-15.

Thebout, Charles M. "A Pure Theory of Local Expenditures," Journal of Political Economy (1956), pp. 416-24.

U.S. Congressional Budget Office. Trends in Public Infrastruc. ture Outlays and The President's Proposals for Infrastructure Spending in 1993, Washington, D.C.: Government Printing Office, May 1992

How Federal Spending for Infrastructure and Other Public investments Affect the Economy, Wastington, D.C.: Government Printing Office, July 1991.

. New Directions for the Nation's Public Works, Washington, D.C.: Government Printing Office, September 1988.

Federal Policies for Infrastructure Management, Washington, D.C.: Government Pinting Office, June 1986.

U.S. Office of Management and Budget. Budget Baselines, Historical Data, and Alternatives for the Future, Washington, D.C.: Government Printing Office, January 1993.

Wall Street Journal. Editorial, "Europe Gets the Message," May 17, 1993.

Washington Post. "Inventing Cintonomics: The Advisers Seeking to Shape Policies Mix Pragmatism, Activism," November 8, 1992. 